\title{
Evaluation of Evolution and Diversity of Maize Open-Pollinated Varieties Cultivated under Contrasted Environmental and Farmers' Selection Pressures: A Phenotypical Approach
}

\author{
Estelle Serpolay-Besson ${ }^{1,2 *}$, Simon Giuliano ${ }^{1,3}$, Nicolas Schermann1, Véronique Chable ${ }^{1}$ \\ ${ }^{1}$ SAD, Cultivated Biodiversity and Participatory Research Team, INRA (French National Research Institute of \\ Agronomical Research), Rennes, France \\ ${ }^{2}$ Cultivated Biodiversity and Participatory Research Team, ITAB (French Technical Institute for Organic \\ Agriculture), Paris, France \\ ${ }^{3}$ UMR 1248 AGIR INRA-INPT; Toulouse University, Institut National Polytechnique de Toulouse-Ecole \\ d'Ingénieurs de Purpan, Toulouse, France \\ Email: ${ }^{*}$ estelle.serpolay-besson@itab.asso.fr
}

Received 22 January 2014; revised 20 February 2014; accepted 19 March 2014

Copyright $@ 2014$ by authors and Scientific Research Publishing Inc.

This work is licensed under the Creative Commons Attribution International License (CC BY).

http://creativecommons.org/licenses/by/4.0/

(c) $\underset{\mathrm{EY}}{\mathrm{EY}}$ Open Access

\begin{abstract}
OPVs (open pollinated varieties) of cross pollinated crops are genetically heterogeneous and therefore likely to evolve over generations, under natural and human selection, which gives them a strong potential for organic and low input farming. OPVs of maize were cultivated and selected by different farmers in France and Italy for 2 generations. The third year, they were phenotypically evaluated for evolution, adaptation and level of diversity (estimated with Nei index) across evolution in a combined on farm and on station experimentation. The results showed that the varieties evolved and even adapted over 2 generations only (especially on maturity traits) but conserved their identity (no evolution of ear morphological traits). They all conserved their diversity, which demonstrated the pertinence of farmers' selection (it is not a bottleneck). These results suggested that the genetically heterogeneous nature of OPVs is an asset for farmers because they can adapt these varieties to specific local conditions and production objectives. Therefore, farmer OPVs should receive more support through social and regulatory recognition, as well as further interest from research.
\end{abstract}

${ }^{*}$ Corresponding author.

How to cite this paper: Serpolay-Besson, E., Giuliano, S., Schermann, N. and Chable, V. (2014) Evaluation of Evolution and Diversity of Maize Open-Pollinated Varieties Cultivated under Contrasted Environmental and Farmers' Selection Pressures: A Phenotypical Approach. Open Journal of Genetics, 4, 125-145. http://dx.doi.org/10.4236/ojgen.2014.42014 


\section{Keywords}

\section{Maize, Zea Mays L., OPVs, Phenotypic Diversity, Phenotypic Evolution, On Farm Evaluation, European Seed Legislation}

\section{Introduction}

The interest for agrobiodiversity has started to be "re-discovered" since a few decades and is still growing up, all over the world, and especially for organic and low input agricultures. Diversity is recognized for its interest for pest and disease management, against abiotic stresses, and it can also increase productivity and long-term stability of the system [1]. However, the seed market is dominated by few homogeneous and large spectrum varieties well adapted to conventional agriculture developed during the Green Revolution [2] [3]. It is particularly the case for maize, a crop of great importance in the world. Maize seed market is today largely dominated by hybrids varieties, especially in Europe. It is clear that the substitution strategy of open pollinated varieties (OPVs) by hybrids has been efficient from a production point of view [4]. Nevertheless, Pixley [3] emphasizes the fact that, if this substitution, associated to an increased use of inputs, allowed an increase in the maize grain production (from around $2 \mathrm{~T} / \mathrm{ha}$ to $8 \mathrm{~T} / \mathrm{ha}$ in the USA), it was detrimental to the net income of the farmers (between 17\% and 38\%), and implied an increase of the loads (between $44 \%$ and $68 \%$ ). These two points induced a reduction of the autonomy of the farmers. Moreover, the introduction of hybrids also contributed to the diminution of the cultivated biodiversity [5] and induced damages on the environment (water, soil and atmosphere quality) met today [6]. Pixley [3], comparing yields of hybrids and OPVs in a meta-analysis, showed that the differences were between $7 \%$ and $20 \%$, to the benefit of the hybrids, across a wide range of locations (on station). However, his study underlined that this difference was reduced in the "marginal environments" where heterogeneous varieties, relatively, perform better. This characteristic has been also emphasized by Ceccarelli [7] who showed the need of specific varieties for these marginal environments. Ceccarelli [7] described these environments: high variability (at various levels of time and space), low fertility, and generally subjected to high stress (drought, high sunshine, altitude, cold,...). Such abiotic stresses are particularly encountered in organic and in low input agriculture since the inputs are not present to counterbalance the environmental conditions.

This lack of varieties, hybrids in particular, adapted to these environments could be the reason why hybrids are less present on the markets, which were the specific environments dominate. Examples are multiple in the literature: hybrids represent only $6 \%$ in some Nepal regions [8], $47 \%$ in all the developing countries and only $34 \%$ in the developing countries were the production levels which are low [9], less than 25\% in Mexico [10] or 63\% in Guizhou region in China [11].

Another reason invocated for the use of OPVs is the specific uses made with certain varieties as polenta in Italy (varieties Biancoperla or Marano in the North-East as examples) or the use of waxy varieties in China [11].

For slightly more than 10 years, some researchers have paid a particular attention to those OPVs, because of their interest for sustainable systems [4] through diversity as a source of evolution and adaptation, especially in the framework of Participatory Plant Breeding (PPB) programs [9] [12]-[14]. Farmers' demand is often at the basis of such projects because of specific agronomical, environmental and sometimes economic conditions which don't allow hybrid cultivation (like the project of Sol da Manha, [13]). In Europe, where the market is strongly dominated by hybrids, there is a lack of genetic accessible diversity on one hand, and a lack in understanding the potential of evolution of maize OPVs on the other hand. Several farmers, interested in such varieties because of specific agronomic, environmental and economic conditions (such as organic and low input farming) and organized in associations in different European countries, asked researchers to investigate this diversity with them.

The European research project Farm Seed Opportunities [15] took into consideration such a demand from farmers for different species, including maize, and studied the evolution potentialities of different OPVs. The hypothesis of this project is that genetic diversity (represented here by OPVs) provides a strong evolution and thus adaptation potential, which is necessary for organic and low input agriculture due to high genotype $\mathrm{x}$ environment (GxE) interactions in these contexts [16]. For this purpose, a specific methodology was developed, similar for all four species studied (spinach, beans, wheat and maize) [17]-[19]. It consisted in submitting different 
populations to contrasted environments in organic and low input farms across Europe (France, Italy and the Netherlands) under diverse environmental and farmers' breeding conditions. After a three-year period, the consequences on the varieties were assessed through a double phenotypical evaluation: on each farm and on station. This evaluation was also made from a diversity point of view. On farm experimentations, involving farmers, and on station evaluation were combined in order to bring complementary information. In this paper, we detail the specific methodology used and the analysis associated. Results will be first presented in terms of evolution and adaptation stricto sensu and then in terms of diversity (degree of evolution of the diversity level according to selection). The pertinence of such an experimental design will be discussed.

\section{Material and Methods}

Our experiment aimed at assessing the evolutionary changes of different maize OPVs grown and multiplied by different farmers. The experiment lasted 3 years (2007-2009) and implied several farmers in France and Italy. The first year, each OPV studied (five OPVs altogether) was given to two or three farmers located in contrasted environments in organic or low input management. Farmers had to cultivate and multiply the OPVs according to their own usual practices (culture and selection). The designation of the population multiplied for two successive years by one farmer is called in the paper the "farmer version". The third year, the original seed lot (named "control version") was given back to each farmer to be cultivated close to the farmer version in order to assess possible changes between the two versions. The same year, the selection pressure (or selection differential) of the farmers was also evaluated by measuring selected and random ears. Furthermore, all the versions of all the farmers were compared in a common trial (called hereafter "on station experiment") to assess divergence among versions within each variety. A hybrid variety was also cultivated on this experiment as a reference for comercial seeds. Table 1 summarizes the proceedings of the trials.

The goal of this experiment was also to study phenotypic diversity within varieties (with a wide range of criteria: UPOV criteria of varietal uniformity and other phenotypic traits) and the impacts that farmers' selection had on phenotypic diversity.

Data was collected on plants in the field during cultivation (on station) and at maturity both on station and on farm; several traits were measured on ears after harvest (see 2.4 Plants measurements). Cultivation conditions and selection criteria were collected as well (Table 2).

\subsection{Varieties}

The five varieties tested were populations (maize OPVs). Sponcio and Biancoperla were provided by IGSA ${ }^{1}$, located in North-Eastern Italy. The three other were provided by the French association AgroBio Périgord, promoting cultivated biodiversity and based in South-West of France.

Information about the different OPVs is provided in Table 3.

\subsection{Locations}

Seven farmers of West of France (CS, BJ and JD), South West of France (JLB, EJ and AD) and North East of Italy (It) participated in this experiment. The common on station trial was located in West of France (in Le Rheu -LR-Britany, close to Rennes). Figure 1 below shows the locations of the trails and Figure 2 shows the general climate conditions (means) in order to describe the contrasts of the environments.

Farmers It, AD and CS had several varieties on their farm but they were not cultivated on the same field in order to avoid crosses. Furthermore, all the trials were always isolated with minimum of 500 meters from any other maize field in order to avoid seed contamination for the following years as it is generally practiced for maize seed production.

\subsection{Experimental Designs}

On farmers' fields, the varieties were multiplied and selected on $1000 \mathrm{~m}^{2}$ plots each year. The third year, the control version was planted next to the farmer version on two replicated blocks (the total area of the trial was about $2000 \mathrm{~m}^{2}$ ). Nevertheless, despite they were conserved in cool and dry conditions, the control versions of

${ }^{1}$ IGSA: Istituto di genetica e sperimentazione agraria Nazareno Strampelli, Lonigo, Italy. 
Table 1. Cultivation locations for one variety along the experiment.

\begin{tabular}{|c|c|c|c|c|c|}
\hline & & $\begin{array}{c}2007 \\
\text { Year } 1\end{array}$ & $\begin{array}{c}2008 \\
\text { Year } 2\end{array}$ & $\begin{array}{l}2009 \text { on farm } \\
\text { Year } 3 \text { (3G) }\end{array}$ & $\begin{array}{c}2009 \text { on station } \\
\text { Year } 3(3 G)\end{array}$ \\
\hline \multirow{2}{*}{ Variety } & Farm 1 & $\begin{array}{l}\text { Control version } \\
\text { (original seed lot) }\end{array}$ & Farm 1 version & $\begin{array}{l}\text { Farm } 1 \text { version } \\
\text { Control version }\end{array}$ & \multirow{2}{*}{$\begin{array}{l}\text { Farm } 1 \text { version } \\
\text { Farm } 2 \text { version }\end{array}$} \\
\hline & Farm 2 & Control version & Farm 2 version & $\begin{array}{l}\text { Farm } 2 \text { version } \\
\text { Control version }\end{array}$ & \\
\hline
\end{tabular}

Table 2. Selection criteria of the farmers.

\begin{tabular}{|c|c|c|}
\hline Farmer & Varieties concerned & Criteria \\
\hline JD & Narguilé & $\begin{array}{l}\text { Elimination of the smuty plants during cultivation. } \\
\text { Selection on health, maturity and height (good to be harvested by hand). } \\
\text { "Non falling" ears were prefered. }\end{array}$ \\
\hline It & All the varieties & Preference for vitreous grain because it's the use of the place. \\
\hline EJ & Italien & Selection on health, maturity (earliest ears) and color (yellow grain, no white). \\
\hline CS & Bianco & $\begin{array}{l}\text { Selection on early maturity as principle criterion. About } 200 \text { ears } \\
\text { collected every year (strong bottleneck). }\end{array}$ \\
\hline CS & GRB & Selection on maturity, health and size (big ears were chosen). \\
\hline JLB & Sponcio & $\begin{array}{c}\text { Selection on the "beautifulness": regularly shaped, straight rows, well filled and mature ears. Ears } \\
\text { without long spathes were preferred. }\end{array}$ \\
\hline $\mathrm{BJ}$ & Italien & Selection on maturity, health, good fecundation and standing \\
\hline $\mathrm{AD}$ & GRB and Narguilé & Selection on health, fecundation, height and plant standing. \\
\hline
\end{tabular}

Table 3. Information about the OPVs tested.

\begin{tabular}{|c|c|c|c|c|}
\hline Population & Origin & Status and uses & Short description & $\begin{array}{l}\text { Estimation of undergone } \\
\text { bottlenecks }\end{array}$ \\
\hline Biancoperla & $\begin{array}{l}\text { Veneto region, } \\
\text { North-East of Italy }\end{array}$ & $\begin{array}{l}\text { Traditional populations of the } \\
\text { region, still cultivated and bred } \\
\text { in the region of origin, destined }\end{array}$ & $\begin{array}{l}\text { Very tall and very late } \\
\text { plants. White small grain. }\end{array}$ & $\begin{array}{l}\text { Varieties still cultivated in their } \\
\text { region of origin, no specific }\end{array}$ \\
\hline Sponcio & $\begin{array}{l}\text { Veneto region, } \\
\text { North-East of Italy }\end{array}$ & $\begin{array}{l}\text { to flour for human consumption } \\
\text { (polenta, traditional dish) }\end{array}$ & $\begin{array}{l}\text { Tall and very late plants. } \\
\text { Small orange pointed grain. }\end{array}$ & bottleneck. \\
\hline Narguilé & $\begin{array}{l}\text { Irak but cultivated } \\
\text { in France for } \\
\text { about } 10 \text { years }\end{array}$ & & $\begin{array}{l}\text { Very tall and late plants. } \\
\text { Yellow grain. }\end{array}$ & $\begin{array}{l}\text { Cultivation started in France } \\
\text { from } 1000 \text { kernels, strong } \\
\text { bottleneck }\end{array}$ \\
\hline $\begin{array}{l}\text { Grand Roux } \\
\text { Basque } \\
\text { (GRB) }\end{array}$ & $\begin{array}{l}\text { Spain Basque } \\
\text { Region and was } \\
\text { given to some } \\
\text { people of French } \\
\text { Basque Region } \\
\text { (South West of } \\
\text { France) }\end{array}$ & $\begin{array}{l}\text { Started to be cultivated by } \\
\text { some farmers in France in } \\
2002 \text { for grain (animal } \\
\text { feeding) and silage. }\end{array}$ & $\begin{array}{l}\text { Quite early. } \\
\text { Reddish corned grain }\end{array}$ & $\begin{array}{l}\text { Difficult to estimate because the } \\
\text { story seems quite old. There } \\
\text { might has been a strong } \\
\text { bottleneck when the variety } \\
\text { arrived in France but it is quite } \\
\text { old (really more than for the } \\
\text { other varieties) }\end{array}$ \\
\hline Italien & Italy & & $\begin{array}{l}\text { Quite late. Light } \\
\text { yellow grain (with a lot of } \\
\text { nuances from white to } \\
\text { rose) }\end{array}$ & $\begin{array}{l}\text { This variety arrived at } \\
\text { AgroBio Périgord at the } \\
\text { beginning of the } 2000 \text { with } 20 \\
\text { ears. There was quite a strong } \\
\text { bottleneck. }\end{array}$ \\
\hline
\end{tabular}

the French varieties (Narguilé, GRB and Italien) didn’t germinate at all and thus made impossible the evolution assessment that was made only for the two Italian varieties (Sponcio and Biancoperla). Because only the farmers CS and JLB had set up the right design (2 replicates), evolution was evaluated only in those places (Table 4). However, in the Italian site, selection differential was though evaluated because there was no need of 

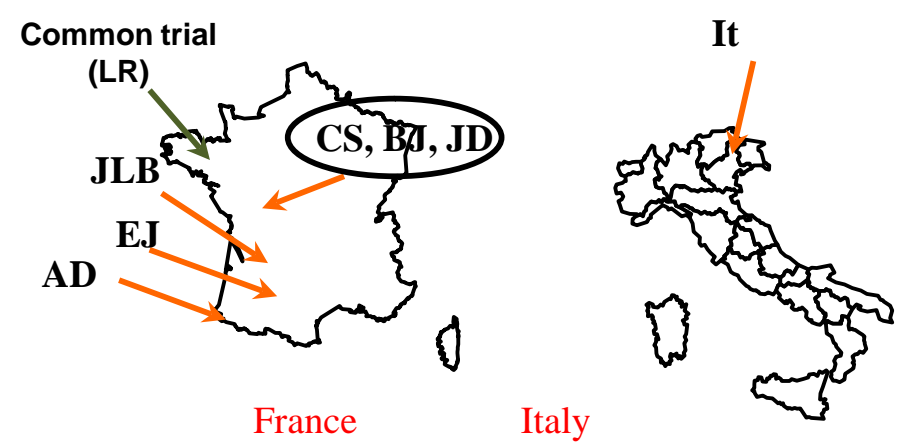

Figure 1. Locations of the trials.

Table 4. Summary of the cultivation locations according to the varieties and versions.

\begin{tabular}{|c|c|c|c|c|c|}
\hline Variety & Farm & 2007 & 2008 & 2009 on farm & 2009 on station \\
\hline \multirow{2}{*}{ Biancoperla } & It & Control version & It version & $\begin{array}{c}\text { It version } \\
\text { Control version }^{*}\end{array}$ & \multirow{2}{*}{$\begin{array}{l}\text { It version } \\
\text { CS version }\end{array}$} \\
\hline & CS & Control version & CS version & $\begin{array}{c}\text { CS version } \\
\text { Control version }\end{array}$ & \\
\hline \multirow{2}{*}{ Sponcio } & It & Control version & It version & $\begin{array}{c}\text { It version } \\
\text { Control version }^{*}\end{array}$ & \multirow{2}{*}{$\begin{array}{l}\text { It version } \\
\text { JLB version }\end{array}$} \\
\hline & JLB & Control version & JLB version & $\begin{array}{l}\text { JLB' version } \\
\text { Control version }\end{array}$ & \\
\hline \multirow{3}{*}{ Italien } & It & Control version & It version & It version & \multirow{3}{*}{$\begin{array}{l}\text { It version } \\
\text { BJ version } \\
\text { AD version }\end{array}$} \\
\hline & BJ & Control version & BJ version & $B J$ version & \\
\hline & $\mathrm{AD}$ & Control version & EJ version & $A D$ version & \\
\hline \multirow{3}{*}{ Narguilé } & It & Control version & It version & It version & \multirow{3}{*}{$\begin{array}{l}\text { It version } \\
\text { JD version } \\
\text { AD version }\end{array}$} \\
\hline & $\mathrm{JD}$ & Control version & JD version & JD version & \\
\hline & $\mathrm{AD}$ & Control version & $A D$ version & $\mathrm{AD}$ version & \\
\hline \multirow{3}{*}{$\begin{array}{c}\text { Grand Roux } \\
\text { Basque (GRB) }\end{array}$} & It & Control version & It version & It version & \multirow{3}{*}{$\begin{array}{l}\text { It version } \\
\text { CS version } \\
\text { AD version }\end{array}$} \\
\hline & $\mathrm{CS}$ & Control version & CS version & CS version & \\
\hline & $\mathrm{AD}$ & Control version & AD version & AD version & \\
\hline
\end{tabular}

*For It location, there was no replicate of each version so the data collected in order to assess evolution of the variety was not used, only data to assess selection differential was used. In dark grey, versions and locations where all the data collected was exploited; in light grey, versions and places where data was only partially exploited.

replicates for this evaluation (see below).

The 2 farms with 2 replicates of each version had not the same design:

1) CS design was a checked pattern. 2 series of 10 consecutive plants were observed per plot and the ears collected (data was called 3G random). In order to evaluate the selection differential, the farmer was asked to select 20 ears in each replicate of his version (called 3G sel).

2) At JLB, the two versions were in alternative strips (4 lines of control, 4 lines of JLB version...). Three series of 10 consecutive plants were observed inside each version in consecutive strips and the ears were collected (3G random). In order to evaluate the selection differential, the farmer was asked to select 10 ears in each of the 3 strips where the plants were observed (3G sel).

The common trial was built according to a nested split-splot design replicated three times. Varieties were used as main plot units and versions within variety were the nested units. This design was retained because it allows more precise comparison among the nested units, which is the goal of the experiment [20].

The basic plot consisted in 4 lines of 7 meters long each (about 35 plants per line); surface of each plot was $22.4 \mathrm{~m}^{2}$. 

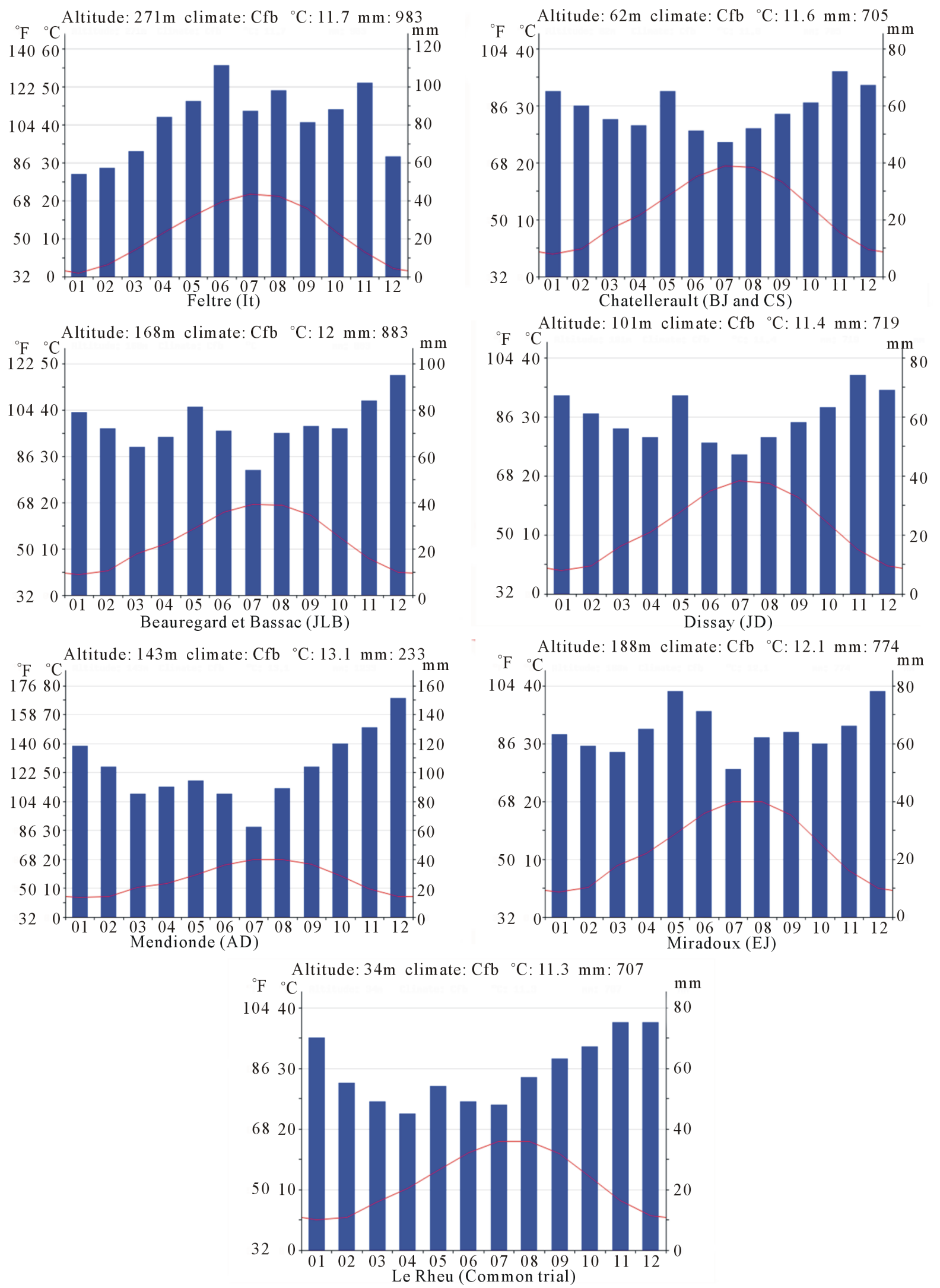

Figure 2. Climatic conditions of the different locations of the trials. 


\subsection{Plants Measurements}

\subsubsection{On Station}

On station, during cultivation, phenotypical and morphological data was collected on 10 to 30 plants per plot (according to the variable measured). The plants observed were located on the center of the plot. The first range of observations took place at flowering time where flowering parameters were measured (date of male and female flowering, silk color for the first ear only when they were more than one). During ripening, morphological parameters were measured (plant and spike insertion height, stem size and corn borer and smut).

The other observations were made at harvesting time where 15 ears per plot were harvested randomly and then measured for ear parameters (ear shape, kernel row arrangement, row number, kernel shape and color, ear length, grain weight, cob color, 100 kernel weight, kernel number per ear, seed moisture, protein, starch and fat content).

\subsubsection{On Farm}

On farm, the observations were only made at harvesting time on a specific number of plants according to the farmers' design explained above (plant and ear height, stem size and smut and corn borer). Ears from control version and third generation were also harvested randomly and then measured for the same ear parameters as on station. Ears from 3G version are called 3G random.

In order to evaluate the selection pressure, the farmers were asked to choose ears from plants of the third generation they would conserve for seed. Those ears were observed for the same traits as the others and they are called 3G sel (for farmers' selection). The means comparison of the 3G random and 3G sel is called the selection differential.

All the observations collected and the modalities are presented in Table 5.

\subsection{Data Analysis}

For both on farm and on station experiments, each variety was analyzed separately by ANOVA for each quantitative trait $Y$ according to the model:

$$
Y_{i j k}=m+\text { replicate }_{i}+\text { version }_{j}+e_{i j k}
$$

where $i$ is the replicate ( 3 on station and 2 on farm), $j$ is the version (CS, AD, JLB, It, BJ, JD and EJ on station and control, $3 \mathrm{G}$ random and sel on farm) and $\mathrm{k}$ is the plant or ear measured; and Chi ${ }^{2}$ tests of the version effect were performed for qualitative traits after pooling the data on all replicates. For on farm experiments, the versions tested were control and third generation (3G random) for one set of analysis, and 3G sel and 3G random for the selection differential set of analysis. For the on station experiment, the versions tested were the farmers' versions between them. For both ANOVA and Chi ${ }^{2}$ tests, we chose a significance threshold of $5 \%$. When the comparison between the control and third generation versions on a farm for a trait was statistically significant, we called that phenotypic evolution hereafter. When the comparison between the 3G sel and 3G random versions was statistically significant for a trait, we considered that it was a trait for which the farmer selected efficiently (selection differential).

Concerning the on station analysis, we said there was divergence among the different farmers' versions of a variety when the tests of the version effect were statistically significant.

Multivariate analysis, Principal Component Analysis (PCA), was performed for quantitative traits only (10 concerning ears and 5 concerning plant development: Plant Height, Ear Height, Stem Size, Flowering dates), with the whole data of the common trial (except the hybrid variety for which there is not different versions), in order to evaluate the distinctness of the varieties.

In the results of the common trial, we did not indicate the mean values for the different versions of a variety, since, in a site such as Le Rheu far away from where the varieties were bred, it is difficult to interpret why each version mean changed as it did (lack of agronomical sense in our eyes). We presented the means of the farm experiments because they had an agronomical sense.

According to [21], Nei index was calculated to evaluate the diversity of each trait of each version in each location. The formula used was

$$
H s=1-\sum_{i} p_{i}^{2}
$$


Table 5. Traits observed and details.

\begin{tabular}{|c|c|c|c|}
\hline \multirow{2}{*}{ Trait } & \multicolumn{2}{|c|}{ Measurements } & \multirow{2}{*}{$\begin{array}{l}\text { Number of plants or ears measured per } \\
\text { version-location }\end{array}$} \\
\hline & On farm & On station & \\
\hline Male flowering & & $\mathrm{X}$ & 90 on station \\
\hline Female flowering & & $\mathrm{X}$ & 90 on station \\
\hline Silk color ${ }^{*}$ & & $\mathrm{X}$ & 90 on station \\
\hline Smut & $\mathrm{X}$ & $\mathrm{X}$ & $\begin{array}{l}90 \text { on station } \\
30 \text { on farm }\end{array}$ \\
\hline Corn borer (pyrale) & $\mathrm{X}$ & $\mathrm{X}$ & $\begin{array}{l}90 \text { on station } \\
30 \text { on farm }\end{array}$ \\
\hline Plant height & $\mathrm{X}$ & $\mathrm{X}$ & $\begin{array}{l}90 \text { on station } \\
30 \text { on farm }\end{array}$ \\
\hline Ear height ${ }^{*}$ & $\mathrm{X}$ & $\mathrm{X}$ & $\begin{array}{c}90 \text { on station } \\
30 \text { on farm }\end{array}$ \\
\hline Stem size & $\mathrm{X}$ & $\mathrm{X}$ & $\begin{array}{l}90 \text { on station } \\
30 \text { on farm }\end{array}$ \\
\hline Ear shape & $\mathrm{X}$ & $\mathrm{X}$ & $\begin{array}{l}45 \text { on station } \\
30 \text { on farm }\end{array}$ \\
\hline Kernel row arrangement & $\mathrm{X}$ & $\mathrm{X}$ & $\begin{array}{l}45 \text { on station } \\
30 \text { on farm }\end{array}$ \\
\hline Row number & $\mathrm{X}$ & $\mathrm{X}$ & $\begin{array}{l}45 \text { on station } \\
30 \text { on farm }\end{array}$ \\
\hline Kernel shape & $\mathrm{X}$ & $\mathrm{X}$ & $\begin{array}{l}45 \text { on station } \\
30 \text { on farm }\end{array}$ \\
\hline Kernel color & $\mathrm{X}$ & $\mathrm{X}$ & $\begin{array}{l}45 \text { on station } \\
30 \text { on farm }\end{array}$ \\
\hline Ear length & $\mathrm{X}$ & $\mathrm{X}$ & $\begin{array}{l}45 \text { on station } \\
30 \text { on farm }\end{array}$ \\
\hline Ear diameter (at mid length) & $\mathrm{X}$ & $\mathrm{X}$ & $\begin{array}{l}45 \text { on station } \\
30 \text { on farm }\end{array}$ \\
\hline Grain weight (homogeneized for $15 \%$ of humidity) & $\mathrm{X}$ & $\mathrm{X}$ & $\begin{array}{l}45 \text { on station } \\
30 \text { on farm }\end{array}$ \\
\hline Cob color & $\mathrm{X}$ & $\mathrm{X}$ & $\begin{array}{l}45 \text { on station } \\
30 \text { on farm }\end{array}$ \\
\hline 100 kernel weight (homogeneized for $15 \%$ of humidity) & $\mathrm{X}$ & $\mathrm{X}$ & $\begin{array}{l}45 \text { on station } \\
30 \text { on farm }\end{array}$ \\
\hline Kernel number per ear & $\mathrm{X}$ & $\mathrm{X}$ & $\begin{array}{l}45 \text { on station } \\
30 \text { on farm }\end{array}$ \\
\hline Seed moisture & $\mathrm{X}$ & $\mathrm{X}$ & $\begin{array}{l}45 \text { on station } \\
30 \text { on farm }\end{array}$ \\
\hline protein & $\mathrm{X}$ & $\mathrm{X}$ & $\begin{array}{l}45 \text { on station } \\
30 \text { on farm }\end{array}$ \\
\hline starch & $\mathrm{X}$ & $\mathrm{X}$ & $\begin{array}{l}45 \text { on station } \\
30 \text { on farm }\end{array}$ \\
\hline Fat & $\mathrm{X}$ & $\mathrm{X}$ & $\begin{array}{l}45 \text { on station } \\
30 \text { on farm }\end{array}$ \\
\hline
\end{tabular}

${ }^{*}$ when more than one ear was present on the plant, only the main ear (the lowest) was considered. ${ }^{* *}$ one version location $=$ all the replicates of one version in one site, e.g. at Le Rheu, the version Biancoperla CS includes the 3 replicates of the common trial

where $p_{i}$ is the frequency of each $i$ class of a qualitative trait (for quantitative traits, the whole population in a site—all versions of all varieties—was divided into 10 classes of equal ranges). 


\section{Results and Discussion}

\subsection{On Station Assessment}

\subsubsection{Divergence among the Farmers' Versions}

The multivariate analysis (Figure 3) showed that varieties diverged but not to a point where they can no longer be recognized: the different versions of each variety were clearly grouped on the three first principal components. The first axis was positively correlated with plant size (PlHi and EarHi, coefficients of correlation respectively of 0.93 and 0.94 ,) and its precocity ( $\mathrm{MlFl}$ and FeFl, 0.68 and 0.70 ) but is negatively linked with EarDiMid $(-0.78)$, GrWe $(-0.70), 100 \mathrm{KrWe}(-0.86)$ and Moisture $(-0.88)$ (Table 6). Thus, Biancoperla, which had the highest score on this component, can be considered a tall and late variety, with a low productivity but also with low moisture at harvest. The second principal component was linked positively with StSiz (0.68), EarDiMid
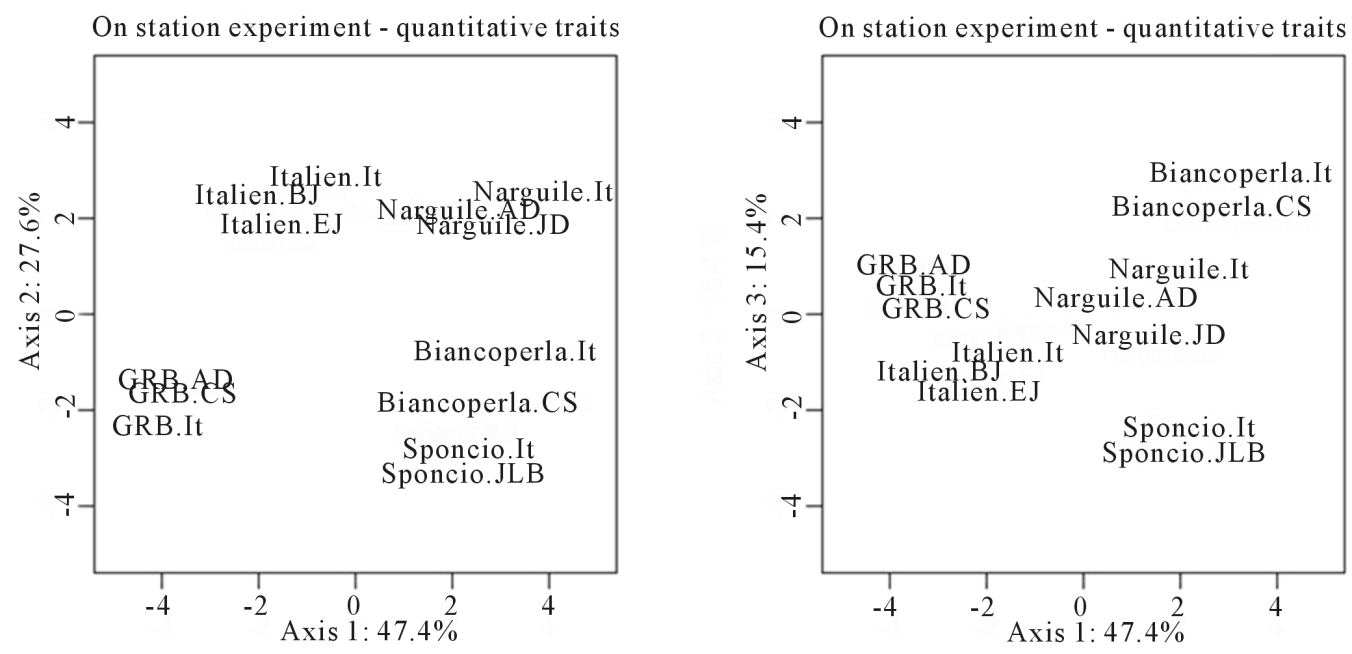

Figure 3. Multivariate analysis (PCA) of quantitative traits measured on plant and ears for the on station experiment. The figure on the left represents the divergence of the different versions of the varieties tested on the 2 first axis of the PCA, the second figure (on the right) presents the same results but on the axis 1 and 3 of the PCA.

Table 6. Coefficients of correlation of quantitative traits for the first 3 axes of the PCA.

\begin{tabular}{cccc}
\hline Traits & Axis 1 & Axis 2 & Axis 3 \\
\hline Plant height & 0.93 & 0.22 & 0.270 \\
Ear height & 0.94 & 0.29 & 0.026 \\
Stem size & 0.11 & 0.68 & 0.670 \\
Male flowering & 0.68 & 0.65 & 0.170 \\
Female flowering & 0.70 & 0.58 & 0.280 \\
Number of rows & 0.45 & 0.57 & -0.630 \\
Ear length & 0.35 & 0.27 & 0.790 \\
Ear mid diameter & -0.79 & 0.61 & -0.032 \\
Grain weight 15\% & -0.70 & 0.43 & 0.040 \\
100 kernel weight 15\% & -0.87 & -0.21 & 0.440 \\
Kernel number per ear & 0.56 & 0.45 & -0.570 \\
Seed moisture & -0.88 & 0.39 & 0.079 \\
Protein & 0.44 & -0.78 & 0.270 \\
Starch & -0.44 & 0.81 & -0.220 \\
Fat & 0.85 & -0.43 & -0.120 \\
\hline
\end{tabular}


(0.61) and Starch (0.81); it is negatively linked with Protein (-0.78). That means that varieties with a high score on that component (Italien and Narguilé) had a vigorous stem, ears with a large diameter and kernels with a high starch and low protein content. Finally, the third axis was also correlated with StSiz (0.67), RwNb (-0.62) and EarLn (0.79). Thus, the main specific characteristics of this axis were ear length and row number. Biancoperla was thus the variety that showed the highest score on this axis, with long ears but few rows (due to a particular width of the kernel).

Table 7 showed that there has been significant divergence between versions of all varieties for flowering,

Table 7. Diversity (Hs) and divergence (ANOVA and $\mathrm{Chi}^{2}$ tests) of farmers' versions within each variety in the on station experiment.

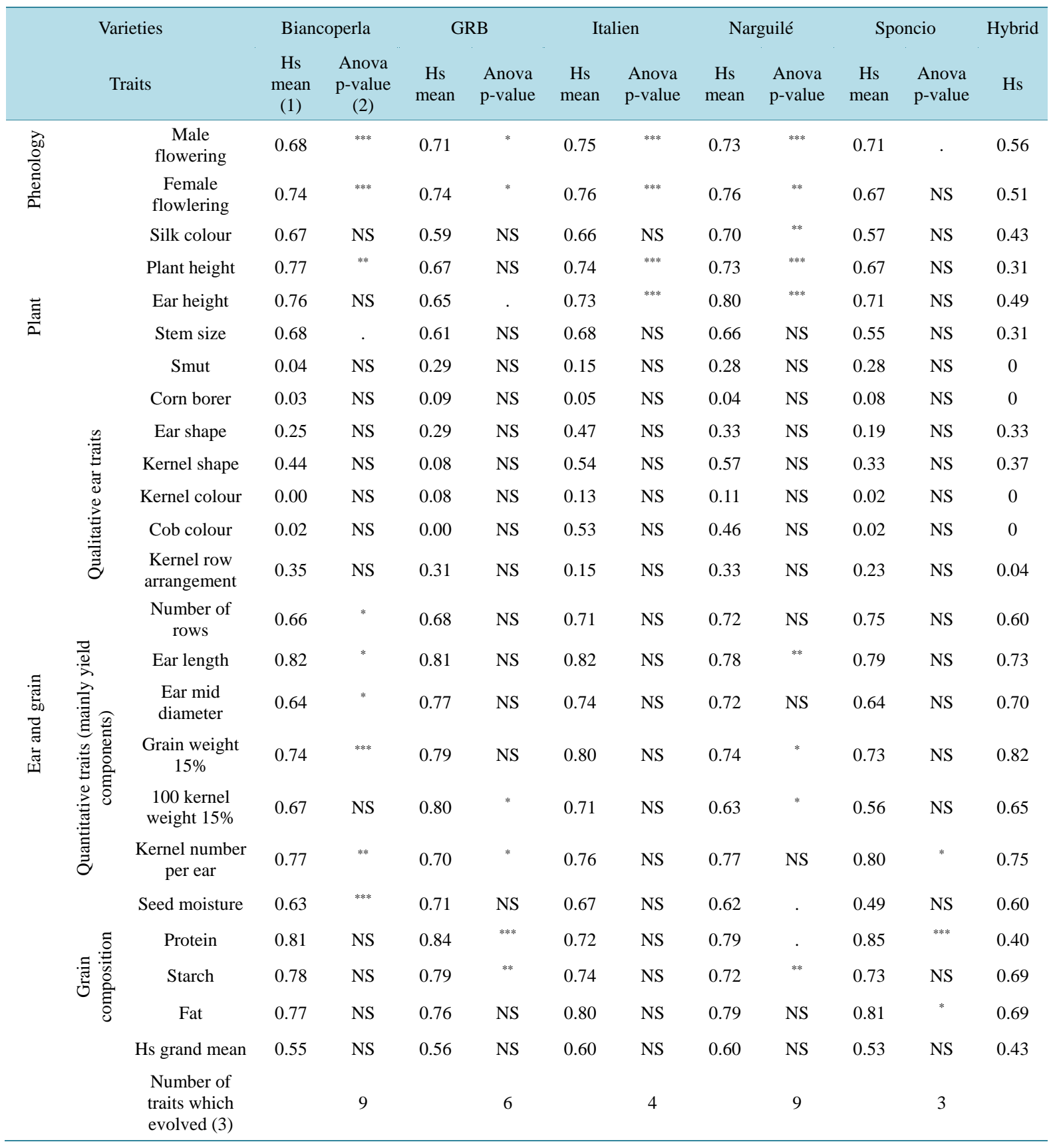

(1) Mean of Hs (Nei Index) values over versions of each variety, (2) Anova p-value of version effect. ${ }^{* * *}$ : p-value $<0.001,{ }^{* *}$ : p-value $<0.01,{ }^{*}$ : p-value < 0.05 , NS: non significant, (3) Number of traits with p-values below 0.05 . 
stem size, plant morphological and ear traits. On the contrary, no divergence was observed neither for ear qualitative traits nor for health aspects (smut and corn borer). For grain composition traits (protein, fat and starch content, seed moisture), only some varieties showed divergence between the different versions (GRB, Narguilé and Sponcio). As far as varieties are concerned, Narguilé and Biancoperla diverged more (9 traits with significant difference between versions) than Italien and Sponcio (respectively 4 and 5 traits with significant evolution).

Statistically significant changes observed in Table 7 were often accompanied by agronomically significant changes. For instance, the two versions of Biancoperla diverged by 3 days for both the female and male flowering time, and by 16 centimeters for plant height, and the 3 versions of GRB diverged by as much as 11 percent for the grain protein content (data not shown).

No divergence was noted for ear qualitative traits (ear and kernel shape, kernel and cob color, kernel row arrangement). On these traits, easily observable, farmers exerted conservative selection for many generations, and these traits are fairly less variable than other traits (see below). Those traits are very characteristic of the varieties and are used for distinctiveness because of their high heritability (descriptors of UPOV and Bioversity protocols). The results showed that the varieties tested didn't change on their phenotypical identity. No divergence between versions was noted for corn borer and smut, but these diseases were very scarce during the year of the experiment.

The 5 varieties studied showed different profiles of divergence for flowering, vigor, plant morphology, ear and grain quantitative traits. Such results suppose that each variety has not the same potential for evolution. It might also be due to the differences of selection pressure of the environment and also by the farmers' conscious and unconscious selections, each variety being cultivated by different farmers with different selection criteria. However, the criteria given by the farmers (see Table 2) were mostly similar.

Firstly, the farmers might not have explained exactly how they did selection (what exactly means "plant standing", what is the selection pressure, is it positive (selection of the best plants) or negative (elimination of the worst plants) selection, on which criteria the selection will be more conservative,...). Moreover, the researchers might not have had the good technique to collect these criteria (e.g. "beautifulness" for JLB) or were not taken into account (e.g. pollination for AD).

\subsubsection{Within-Variety Diversity}

In Table 7, we did not report the within-version heterogeneity values but the mean over versions of each variety, since, for each trait, versions had very similar heterogeneity values (in almost all cases, not exceeding 0.1 differences). This means that all the evolutions undergone by the varieties (including farmers' selection) conserved the same level of diversity as the initial variety (this is also in agreement with on farm results and the Hs index measured) and that farmers' breeding on those open pollinated varieties does not represent strong bottlenecks.

The global levels of diversity of all the OPVs were mostly similar (0.53 to 0.6). This is to put into perspective with the estimation of undergone bottleneck (Table 2). There was no logical links because the variety which was theoretically submitted to the strongest bottleneck (Narguilé) had one of the highest levels of heterogeneity (0.6) and the two Italian varieties which were not submitted to strong bottleneck had a lower level of diversity. These observations were quite surprising but our estimation of diversity was maybe not enough complete.

As far as types of traits are concerned, in Table 7, within-version heterogeneity values for ear qualitative traits were notably smaller than ear quantitative traits, vigor and flowering traits $(0-0.5$ versus $0.5-0.8)$. This is still in agreement with the role of characterization of such traits.

In comparison to the commercial hybrid, the 5 OPVs were globally more heterogeneous (mean of all the Hs per variety, 0.55 to 0.62 for the populations and 0.43 for the hybrid). Looking at the different traits observed, this tendency was confirmed for male and female flowering date ( 0.7 versus 0.5 for the hybrid), silk color (0.6 versus 0.4 ), plant height and stem diameter (0.5 - 0.7 versus 0.3$)$, spike insertion height (0.7 versus 0.5$)$ and protein content $(0.8$ versus 0.4$)$. The diversity for these traits, along with fair levels of heritability means farmers have a lever for efficient on farm selection and adaptation.

For ear traits, except for protein content, whether quantitative or qualitative, there were different levels of heterogeneity values according to varieties. On the whole, the heterogeneity values of the hybrid fell within the range of those of the OPVs for each trait.

More data (several hybrid varieties, sites and climatic years) would be needed to draw general conclusions, but it appeared from the experiment that OPVs have been notably more diverse than commercial hybrid varieties 
for important adaptive traits to the environment (pedo-climatic conditions and farmers' requirements) such as flowering dates, vigor traits and spike insertion height. However, for ear traits (of productive interest), except protein content, they were not more heterogeneous than hybrids. OPVs would have a more important potential of adaptation than hybrid, potential which is looked for by farmers-breeders. This confirmed that OPVs are a better fitting genetic structures for them than the hybrid tested, especially as cultivation conditions significantly differ from the ones prevailing during the selection and registration of hybrids. The hybrid variety, in spite of being selected for its "homogeneity" according to the UPOV criteria, didn't show this homogeneity on the characters not taken into account on the registration.

As a conclusion, despite the divergence among farmers' versions that showed a relative evolution, varieties have conserved both their diversity and their distinctive characteristics. The comparison with a hybrid in terms of diversity showed a potential advantage of the OPVs for precocity traits and plant characteristics adaptation.

In the following part, we will complete these on station results by on farm ones and see if they match.

\subsection{On Farm}

\subsubsection{Selection Differential}

According to the different tables of ANOVA tests (Tables 8-11), all the farmers applied a strong and diverse selection pressure on ear quantitative traits (significant differences between 3G random and 3G sel) whereas selection on qualitative traits was more conservative (no significant differences for those traits between $3 \mathrm{G}$ random and $3 \mathrm{G}$ se). It means that the farmers kept the identity of the varieties they grew, essentially based on qualitative traits.

When they selected ears, farmers always chose the most productive ears even if they didn't explicitly say so (see Table 2). Means of yield components were often significantly higher for 3G sel than 3G random; as an example, farmers always selected significantly longer ears (12.5 to $16.9 \mathrm{~cm}$ for Bianco CS, 21.8 to $23.8 \mathrm{~cm}$ for Bianco It, 16.1 to 18.2 for Sponcio It and 15.6 to 18.3 for Sponcio JLB).

As far as grain composition traits is concerned (moisture, protein, starch and fat), selected ears often showed significantly higher moisture for three of the farmers. This is in contradiction with the fact that they wanted to select more mature ears in order to adapt varieties to their location. However, this observation can be balanced by the fact that they selected "longer" and "heavier" ears, and this might mislead and induce them to confuse heavier and less dry ears. Moisture value can appear very low. They have been measured a certain time after harvest. However, all the ears were conserved in the same conditions and thus, the moisture values are still

Table 8. Means, selection differential (ANOVA) and diversity (Hs) of Sponcio It.

\begin{tabular}{|c|c|c|c|c|c|}
\hline Traits & Mean 3g Has & Mean 3g Sel & Signification test (ANOVA or Tuckey) & Hs 3G random & Hs 3G sel \\
\hline Ear shape & & & NS & 0.491 & 0.42 \\
\hline Kernel shape & & & NS & 0 & 0 \\
\hline Kernel color & & & NS & 0 & 0 \\
\hline Cob color & & & NS & 0 & 0 \\
\hline Kernel Row Arrangement & & & NS & 0.331 & 0.464 \\
\hline Number of rows & 14.8 & 15.1 & NS & 0.696 & 0.744 \\
\hline Ear length & 16.1 & 18.2 & $* * *$ & 0.798 & 0.8 \\
\hline Ear mid diameter & 3.76 & 3.91 & $*$ & 0.844 & 0.836 \\
\hline Grain weight $15 \%$ & 99 & 121 & $* * *$ & 0.849 & 0.853 \\
\hline 100 kernel weight $15 \%$ & 20.8 & 22 & NS & 0.819 & 0.836 \\
\hline Kernel number per ear & 462 & 556 & ** & 0.84 & 0.793 \\
\hline Seed moisture & 13.8 & 13.5 & $*$ & 0.832 & 0.796 \\
\hline Protein & 11.5 & 11.2 & NS & 0.865 & 0.891 \\
\hline Starch & 69.1 & 69.3 & NS & 0.857 & 0.873 \\
\hline \multirow[t]{2}{*}{ Fat } & 5.79 & 5.72 & NS & 0.819 & 0.798 \\
\hline & & & Hs mean & 0.603 & 0.607 \\
\hline
\end{tabular}


Table 9. Means, selection differential (ANOVA) and diversity (Hs) of Sponcio JLB.

\begin{tabular}{cccccc}
\hline Traits & Mean 3g Has & Mean 3g Sel & Signification test (ANOVA or Tuckey) & Hs 3G random & Hs 3G sel \\
\hline Ear shape & & & NS & 0.128 & 0.0644 \\
Kernel shape & & & NS & 0.358 & 0.18 \\
Kernel color & & & NS & 0 & 0 \\
Cob color & & & NS & 0.0666 & 0.184 \\
Kernel Row Arrangement & & & NS & 0.73 & 0.749 \\
Number of rows & 15.9 & 15.7 & NS & 0.851 & 0.742 \\
Ear length & 15.6 & 18.3 & $* * *$ & 0.847 & 0.851 \\
Ear mid diameter & 3.72 & 3.9 & $* * *$ & 0.832 & 0.704 \\
Grain weight 15\% & 98.3 & 128 & $* *$ & 0.832 & 0.84 \\
100 kernel weight 15\% & 17.4 & 19.9 & $* * *$ & 0.724 & 0.662 \\
Kernel number per ear & 515 & 662 & $* * *$ & 0.797 & 0.767 \\
Seed moisture & 9.69 & 9.96 & $*$ & 0.854 & 0.778 \\
Protein & 10.2 & 11 & $*$ & 0.848 & 0.713 \\
Starch & 69.7 & 68.7 & NS & Hs mean & 0.864
\end{tabular}

Table 10. Means, selection differential (ANOVA) and diversity (Hs) of Biancoperla CS.

\begin{tabular}{|c|c|c|c|c|c|}
\hline Traits & Mean 3g Has & Mean 3g Sel & Signification test (ANOVA or Tuckey) & Hs $3 \mathrm{G}$ random & Hs 3G sel \\
\hline Ear shape & & & NS & 0.32 & 0,238 \\
\hline Kernel shape & & & NS & 0.26 & 0,328 \\
\hline Kernel color & & & NS & 0 & 0 \\
\hline Cob color & & & NS & 0 & 0 \\
\hline Kernel Row Arrangement & & & NS & 0.153 & 0.247 \\
\hline Number of rows & 11.8 & 12.4 & NS & 0.638 & 0.635 \\
\hline Ear length & 12.5 & 16.9 & ${ }^{* * *}$ & 0.855 & 0.801 \\
\hline Ear mid diameter & 3.25 & 3.61 & $* * *$ & 0.759 & 0.759 \\
\hline Grain weight $15 \%$ & 73.8 & 104 & $* * *$ & 0.805 & 0.88 \\
\hline 100 kernel weight $15 \%$ & 20.7 & 23.5 & . & 0.789 & 0.867 \\
\hline Kernel number per ear & 267 & 416 & $* * *$ & 0.843 & 0.835 \\
\hline Seed moisture & 9.43 & 9.56 & NS & 0.805 & 0.813 \\
\hline Protein & 8.73 & 8.53 & NS & 0.859 & 0.845 \\
\hline Starch & 70.1 & 70.2 & NS & 0.773 & 0.838 \\
\hline \multirow[t]{2}{*}{ Fat } & 5.84 & 5.72 & NS & 0.805 & 0.87 \\
\hline & & & Hs mean & 0.578 & 0.597 \\
\hline
\end{tabular}

comparable. For the other grain composition traits, Fat never changed, Starch was lower for 2 farmers (Bianco It and Sponcio JLB) and Protein was higher at JLB (Sponcio variety). These results and the experimental design did not allow us to say that farmers were able to select ears with interesting grain composition characteristics. However, this question is a recurring one asked by French farmers-breeders. Indeed, they have often observed a decrease in grain protein content and would like to know if it could be linked with phenotypical aspects, helping them to control selection for such a trait. Collaborations with groups of farmers are being built in the framework of some projects with the view to deepen this question. Collaboration with scientists and researchers is also asked by the farmers in this context. Thanks to their tools, scientists can help farmers to characterize better their 
varieties and selections.

For all the farmers, the global Nei indexes are very similar between 3G random and 3G sel ( 0.59 and 0.62 for Bianco CS, 0.63 and 0.59 for Bianco It, 0.62 and 0.62 for Sponcio It and 0.60 and 0.55 for Sponcio JLB) and all the Nei indexes per trait have similar levels too (see Tables 8-11). These results confirmed the on station ones: in spite of the selection process, diversity was conserved by farmers. This is opposite to the common belief that selection acts as a strong bottleneck. It is interesting to note that it was in agreement with the sayings of the French farmers at least who claimed that they paid attention on conserving diversity while they chose plants and ears for seed. Our results statistically confirm this statement, from a phenotypical point of view at least.

\subsubsection{Evolution of the Varieties}

Despite a strong selection differential observed, the evolution of the two varieties Sponcio and Biancoperla was very limited after 2 years of cultivation and breeding by the farmers. There was no evolution on qualitative traits (no significant differences between 3G and Control, see Table 12 and Table 13), confirming the previous results on station and deriving for the selection differential not applied on these highly heritable but not very variable traits. There were no differences either on yield component traits (excepted for Bianco CS, the selected version had a significantly higher kernel number per ear). Both varieties significantly evolved on the height of spike insertion (81.7 cm to $94.6 \mathrm{~cm}$ for Bianco CS and $135 \mathrm{~cm}$ to $123 \mathrm{~cm}$ for Sponcio JLB) and also on moisture, showing a response to farmers' selection and explaining the results observed on station. Height of spike insertion might be linked with the height of the farmer and the facility of harvesting ears by hand.

Both third generations had a significantly lower percentage of moisture $(9.42 \%$ versus $9.59 \%$ for Bianco CS and $9.69 \%$ versus $9.88 \%$ for Sponcio JLB). Thus varieties might adapt their cycle to the sites of CS and JLB, reducing their precocity and maturing more rapidly. Indeed, Biancoperla and Sponcio were very late varieties (indexes 600 and 550) compared to the varieties usually cultivated by the farmers CS and JLB (indexes 350 400). These results matched with the results on station which identified maturity traits and plant and spike heights as evolving traits.

Concerning Biancoperla CS, it was very surprising to us that the results did not show any evolution on quantitative traits. It was in contradiction with field and ears observations. If we look more in detail at the data for this variety at CS, we can say that this absence of evolution of Biancoperla on quantitative traits may be erroneous. In the control version, a certain number of ears were not mature and sometimes even not pollinated. For all the versions, some ears had not enough grain to evaluate Seed moisture, Protein, Fat and Starch (which resulted

Table 11. Means, selection differential (ANOVA) and diversity (Hs) of Biancoperla It.

\begin{tabular}{|c|c|c|c|c|c|}
\hline Traits & Mean 3g Has & Mean 3g Sel & Signification test (ANOVA or Tuckey) & Hs 3G random & Hs 3G se \\
\hline Ear shape & & & NS & 0.498 & 0.498 \\
\hline Kernel shape & & & NS & 0 & 0 \\
\hline Kernel color & & & NS & 0 & 0 \\
\hline Cob color & & & NS & 0 & 0 \\
\hline Kernel Row Arrangement & & & NS & 0.487 & 0.32 \\
\hline Number of rows & 14 & 13 & ** & 0.596 & 0.584 \\
\hline Ear length & 21.8 & 23.8 & ** & 0.853 & 0.691 \\
\hline Ear mid diameter & 4.39 & 4.48 & NS & 0.864 & 0.84 \\
\hline Grain weight $15 \%$ & 160 & 183 & ** & 0.842 & 0.769 \\
\hline 100 kernel weight $15 \%$ & 31.9 & 35.3 & ** & 0.844 & 0.818 \\
\hline Kernel number per ear & 506 & 520 & NS & 0.847 & 0.7 \\
\hline Seed moisture & 16.3 & 20.1 & $* * *$ & 0.776 & 0.847 \\
\hline Protein & 10.1 & 10.3 & NS & 0.84 & 0.833 \\
\hline Starch & 69.3 & 68.7 & $*$ & 0.862 & 0.847 \\
\hline \multirow[t]{2}{*}{ Fat } & 6.03 & 6.14 & NS & 0.86 & 0.858 \\
\hline & & & Hs mean & 0.611 & 0.574 \\
\hline
\end{tabular}


Table 12. Means, evolution (ANOVA) and diversity (Hs) of Biancoperla CS.

\begin{tabular}{|c|c|c|c|c|c|}
\hline Traits & Mean 3G & Mean Ctrl & Signification ANOVA Version & Hs 3G & Hs Ctrl \\
\hline Plant height & 184 & 191 & NS & 0.862 & 0.835 \\
\hline Ear height & 81.7 & 94.6 & * & 0.808 & 0.795 \\
\hline Stem size & 1.55 & 1.85 & NS & 0.564 & 0.645 \\
\hline Smut & & & NS & 0 & 0.0488 \\
\hline Corn borer & & & NS & 0.0488 & 0.219 \\
\hline Ear shape & & & NS & 0.32 & 0.255 \\
\hline Kernel shape & & & NS & 0.26 & 0.375 \\
\hline Kernel color & & & NS & 0 & 0 \\
\hline Cob color & & & NS & 0 & 0 \\
\hline Kernel Row Arrangement & & & NS & 0.153 & 0 \\
\hline Number of rows & 11.8 & 11.9 & NS & 0.638 & 0.493 \\
\hline Ear length & 12.5 & 11.3 & NS & 0.876 & 0.848 \\
\hline Ear mid diameter & 3.27 & 3.12 & NS & 0.763 & 0.816 \\
\hline Grain weight $15 \%$ & 75.4 & 75.4 & NS & 0.734 & 0.8 \\
\hline 100 kernel weight $15 \%$ & 20.9 & 21.6 & NS & 0.836 & 0.72 \\
\hline Kernel number per ear & 271 & 199 & * & 0.859 & 0.841 \\
\hline Seed moisture & 9.42 & 9.59 & . & 0.797 & 0.72 \\
\hline Protein & 8.93 & 8.9 & NS & 0.867 & 0.84 \\
\hline Starch & 70 & 70.4 & NS & 0.844 & 0.82 \\
\hline \multirow[t]{2}{*}{ Fat } & 5.8 & 5.66 & NS & 0.836 & 0.74 \\
\hline & & & Hs mean & 0.553 & 0.541 \\
\hline
\end{tabular}

Table 13. Means, evolution (ANOVA) and diversity (Hs) of Sponcio JLB.

\begin{tabular}{|c|c|c|c|c|c|}
\hline trait & Mean 3G & Mean Ctrl & Signification ANOVA Version & Hs 3G & Hs Ctrl \\
\hline Plant height & 258 & 251 & NS & 0.822 & 0.838 \\
\hline Ear height & 135 & 123 & $*$ & 0.864 & 0.847 \\
\hline Stem size & 2.63 & 2.67 & NS & 0.736 & 0.684 \\
\hline Smut & & & NS & 0.18 & 0.231 \\
\hline Corn borer & & & NS & 0.358 & 0.391 \\
\hline Ear shape & & & NS & 0.128 & 0.0644 \\
\hline Kernel shape & & & NS & 0.358 & 0.278 \\
\hline Kernel color & & & NS & 0 & 0 \\
\hline Cob color & & & NS & 0 & 0 \\
\hline Kernel Row Arrangement & & & NS & 0.0666 & 0 \\
\hline Number of rows & 15.9 & 15.7 & NS & 0.713 & 0.782 \\
\hline Ear length & 15.6 & 15.2 & NS & 0.858 & 0.869 \\
\hline Ear mid diameter & 3.72 & 3.7 & NS & 0.849 & 0.849 \\
\hline Grain weight 15\% & 98.3 & 98.4 & NS & 0.867 & 0.892 \\
\hline 100 kernel weight 15\% & 17.4 & 18.6 & NS & 0.838 & 0.868 \\
\hline Kernel number per ear & 515 & 485 & NS & 0.816 & 0.84 \\
\hline Seed moisture & 9.69 & 9.88 & ${ }^{* *}$ & 0.832 & 0.833 \\
\hline Protein & 10.2 & 10.5 & NS & 0.854 & 0.816 \\
\hline Starch & 69.7 & 69 & NS & 0.848 & 0.84 \\
\hline \multirow[t]{2}{*}{ Fat } & 5.54 & 5.72 & NS & 0.87 & 0.858 \\
\hline & & & Hs mean & 0.593 & 0.589 \\
\hline
\end{tabular}


in the impossibility to calculate grain weight at $15 \%$ and HKW at $15 \%$ ). In such cases, we considered that the data was not available (NA), so the number of observations was reduced which affected the calculations that were certainly not anymore representative of the samples. In order to have an idea of this bias, we propose two illustrations, the first one (Table 14), showing the proportions of missing data for each version and the second one (Figure 4), showing photos of all the ears sampled. More than one third of the data was missing for the control version (and more than half of them for seed moisture), instead no or few data was missing for the other versions. This questions the conclusions of the tests primarily presented. Indeed, when data was not available, it means that "ears" had very unfavorable quantitative traits because not even formed. The fact that for third generation, more "analyzable" ears could be collected was a sign of evolution and even of adaptation to the place: the plants of that variety increased their productivity at CS place. The choice of presenting the results in such a way can be discussed but we chose this solution in order to homogenize the calculations and presentations of the results for all varieties and versions (this problem of data occurred only for Biancoperla CS). As far as photos are relevant, they are very clear and let us suppose that the evolution of Biancoperla at CS was really strong instead of what the data analysis expressed. Another argument is that the farmer did not want to cultivate the variety at the beginning of the experiment because of its very late maturity. He accepted to do the experiment anyway and played the game of breeding. At the end of the three years of experiment, he decided to keep the variety for his farm because he found that the protein content was very interesting and the variety very adaptable ... This is maybe the best proof of the co-evolution, and even adaptation of this variety!

For the two varieties observed, the global level of diversity (means of Hs of all the traits for each version) was the same between Control and 3G versions (0.57 and 0.56 for the two versions of Bianco CS and 0.62 and 0.61

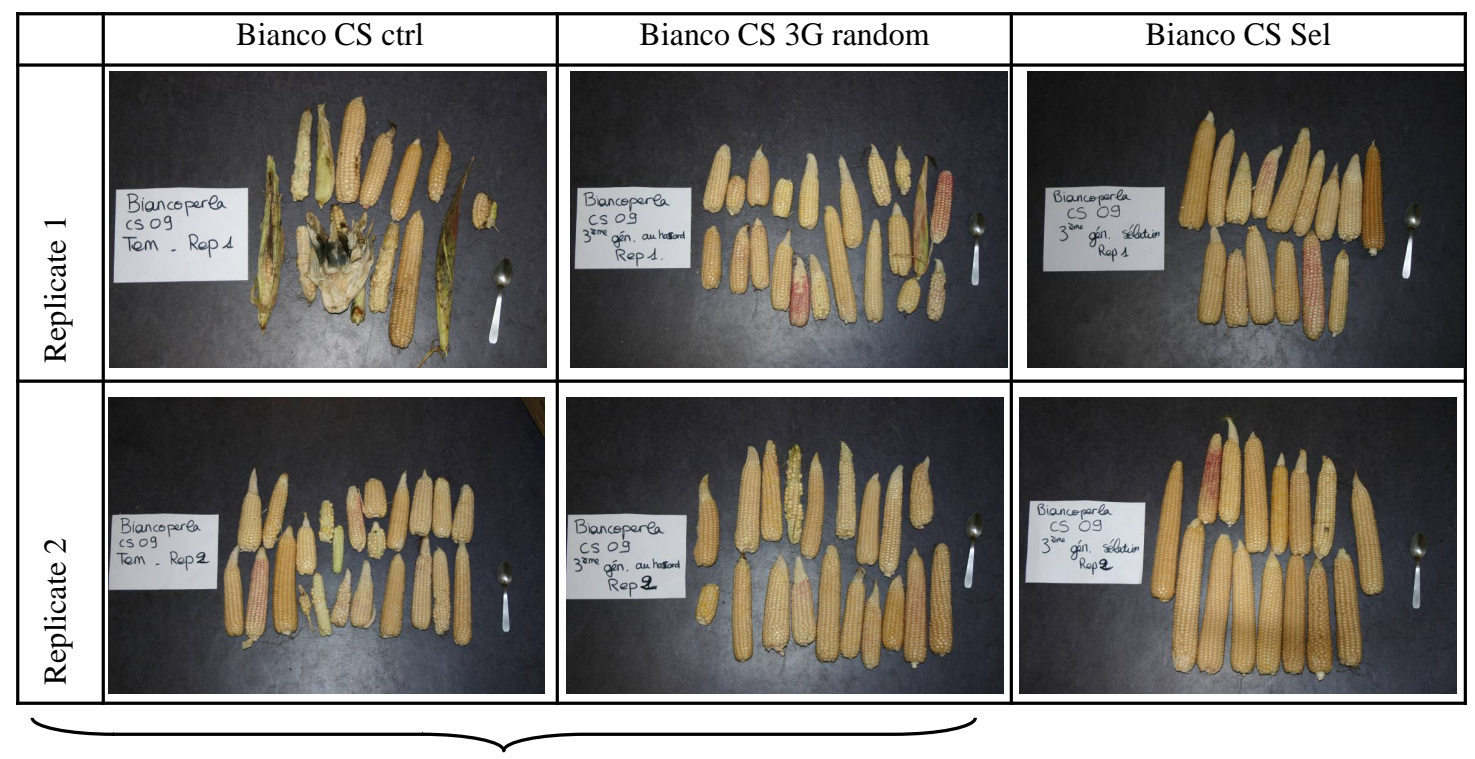

Evaluation of evolution

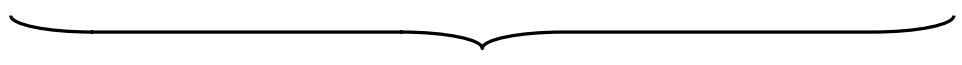

Selection differential

Figure 4. Photos of ears collected at CS location in third generation. A spoon takes place as a scale on the right of each photo.

Table 14. Proportion of missing data on Biancoperla CS ears measured on farm.

\begin{tabular}{ccc}
\hline Version & $\begin{array}{c}\text { Totally missing data/total ears collected = proportion } \\
\text { of missing data }\end{array}$ & $\begin{array}{c}\text { Missing seed moisture data/total ears } \\
\text { collected = proportion of missing data }\end{array}$ \\
\hline Bianco CS ctrl & $13 / 33=0.39$ & $23 / 33=0.7$ \\
Bianco CS 3G random & $0 / 39=0$ & $23 / 39=0.59$ \\
Bianco CS 3G sel & $0 / 29=0$ & $4 / 29=0.14$ \\
\hline
\end{tabular}


for the two versions of Sponcio JLB). The same similarity was observed for each trait of each variety. Noticeable differences $(>0.15)$ were observed for Bianco CS for the traits Corn borer, Kernel Row Arrangement and Row Number. For the corn borer index, the reduced diversity for 3G version means was due to less corn borer on $3 G$ plants. Health of this variety was increased at CS probably due to a higher vigor of the plants at this place. For Kernel Row Arrangement and Row Number, the diversity was higher for 3G version (respectively 0.153 vs 0 and 0.638 vs 0.493 ), meaning that evolution and selection have increased the level of diversity for these traits. This agrees with the objectives of selection of the farmer which has included diversity.

The fact that Bianco CS conserved its level of diversity is very interesting because this variety was submitted to a strong bottleneck each year of cultivation. The first two years of the experimentation, there were about 200 ears collected for selection instead of a minimum of 600 asked, because of the too late maturity; this induced a very strong selection pressure. And in spite of this, diversity was conserved. Several hypotheses can be made: maybe this variety has a high intrinsic diversity level since it is an open pollinated variety, or maybe it is due to the selection of the farmer. A combination of these two parameters is another possibility.

These results obtained on farm matched with the tendencies observed on station. They showed that the varieties conserved their identity and their level of diversity despite a strong selection differential (meaning that farmers' selection conserved diversity of the OPVs). The selection differential is indeed not applied on qualitative traits (with no or low GxE interactions and used as descriptors of varieties in UPOV of Bioversity protocols) but on quantitative ones. Both varieties adapted to the sites from a maturity point of view. A strong adaptation of Biancoperla on quantitative traits could be detected in the field, showing a high plasticity for this variety.

\section{General Discussion}

\subsection{Experimental Design: On Farm Trials and Networks}

The experimental design presented in this study used complementary advantages of both on station and on farm trials, as there are complementarities between genetic conservation on station and on farm [22]. On station trial allowed more regular observations for phenological and development traits (e.g. to determine the date of flowering, the trials were noted every 2 or 3 days which was impossible to do on farm 1) by the researchers since on farm trials were too distant to the research station and 2) by the farmers because it was a time consuming observation). However the on station trials implied a bias in the evaluation of evolution: the varieties grown for only two years in a different environment from their origin have once again undergo another huge change in their environment that probably modified their behavior with a diverse intensity according to the variety considered. In order to facilitate the interpretation of on station trials, they should have to be with the highest proximity of the on farms trials, as referred by [8]. However, it would be needed as many on station trials as there were regions with on farm trials. But a structure of that type would have been much harder to create, especially for a cross-pollinated crop as maize that unable the multiplication of several varieties in the same field. That's probably a reason why this kind of study is very rare, especially in industrialized country were hybrid varieties totally dominate the market and thus research on OPVs is very low [3].

One of the main advantages of the present study over existing works is that evolution of OPVs was observed on farm, in the very place where they evolved, so without the confounding effect of genotype-by-environment interactions. However, it was a pity that we could use the complete data of only on 2 trials. This underlines the importance of collaboration with farmers beforehand, so that they can understand the experiment and the necessities from research.

From a statistical point of view, replicates on farm are necessary in order to buffer agronomical variations and soil conditions. It is not possible, and not suitable, for farmers to sow a trial with so many replicates as on station. This is why we proposed the trade-off of 2 big $\left(500 \mathrm{~m}^{2}\right)$ replicates on farm (which seemed a minimum to buffer agronomical condition), which was a minimum from research point of view and still feasible from farmers' point of view. Then, we increased the number of measurements per replicate in order to reduce the standard deviation of the data and increase the statistical power of the trial.

This trade-off, as all trade-off, needs a phase of consulting beforehand which was lacking here for the Italian trials. Participation of the farmers in on farm trials has to be well discussed before the trials, whatever is their level of implication which can be very diverse according to the project as Pimbert gives examples [23].

Genetic diversity evaluation could be completed by molecular analysis to evaluate its correlation the phenotypic characteristics measured here as it was done for the wheat trials of this project [24]. 


\subsection{Rapidity of Evolution}

Despite its limits, this experimental design was innovative and led us to very interesting results such as the rapidity of evolution of the OPVs tested. Indeed, the duration of the experiment conducted was much shorter than other studies of this type: our trial lasted for 3 years whereas the over studies on that type lasted for 7 years [25] or 26 [26] for maize, or 10 years [27], for wheat. Obviously, the distribution of a wide range of varieties over a wide range of environments stimulated evolution. The combination of these displacements and human selection led to the quick response of the plants.

The results showed that the OPVs tested evolved especially for phenologic traits (duration of the cycle) over 2 generations. This confirms results obtained by Durand [25] from inbred lines but more rapidly for populations in our case.

\subsection{Interest of Maize OPVs and Farmers Selection for Organic and Low Input Agriculture in Europe}

Based on these results, we suggest that thanks to their inherent genetic diversity, maize populations have a strong potential of evolution and thus adaptation to new conditions when subjected to mass selection. This characteristic will probably be an advantage in the future since climate change induces climatic conditions more and more variable [28].

It also confirms the efficiency of farmers' mass selection. This is particularly interesting in organic and low input systems when the conditions are less buffered by inputs and thus where the heterogeneity leads to better agronomic performances of the culture and to a higher resilience of the system [9] [29] [30]. Dawson [19] highlighted the importance of farmers' selection for maintaining productivity. Indeed, in the similar experiment made on wheat (two generations of multiplication and a third year of comparison with initial version, on farm and on station), productive traits were not maintained whereas genetic structure of wheat farmer varieties is robust since wheat is autogamous. The major difference between wheat and maize experiments is that in the wheat experiment, the populations were not subjected to human selection. It might have been the same for maize if conservative selection would not have been exerted, especially as maize is an allogamous species with an uncontrolled pollination.

\subsection{Diversity Level and Divergence}

If the diversity of the varieties is considered as a potential of evolution (the more important the diversity is, the more the variety has possibilities to evolve; [31]) and intensity of evolution as the number of traits which diverged, it can be hypothesized that a higher variability in a variety will lead to a greater evolution (we consider here only the number of traits for evolution and not the \% of evolution because on station we were not in production conditions). Our results showed that the different OPVs had mostly the same level of diversity but not the same intensity of evolution and thus didn't confirm the hypothesis. Furthermore, the intensity of evolution might be only partly due to the level of diversity but other important factors, as selection, were certainly implied. The impact selection pressures (natural and farmers' one), was difficult to evaluate precisely in our experiment scheme. Those selection pressures were though very different for each variety but it was very difficult to quantify them. Indeed, the displacement of a variety from West of France to Northern Italy is more drastic than the introduction of a variety of South-West of France to another farmer of the same region for example. Also, even if we could identify farmers' selection criteria, we were not able to quantify their selection pressure. This double phenomenon implied a bias in the comparison of divergence but don't change the result that the varieties evolved. This question of relationships between level of diversity and potential of evolution linked with selection pressure in the time would need further investigations and a specific experiment allowing separating the effects of natural and several levels of human selection pressures.

\subsection{Distinctiveness/Uniformity/Stability and Variety Registration}

The results showed that the OPVs studied evolved on some traits sensitive to the environmental and human pressures exerted but remained distinct (the qualitative traits did not show evolution and the quantitative traits remained in a certain range around the "usual" mean). The distinctiveness is based on ear characteristics, which 
strongly differ for one variety to the other (e.g. kernel color for Biancoperla or kernel shape for Sponcio). This is also observed by Louette [32] in Mexico, on traditional populations even submitted to gene flows: under farmers' breeding practices, ear characteristics are maintained while other characteristics can evolve. Even if farmers could also decide to create a new variety by selecting on special traits, this distinctiveness seems to be sufficient for the farmer as far as the adaptation to their conditions is concerned. Indeed, we demonstrated that diversified varieties have potentialities to adapt (especially for maturity) to organic and low input agriculture which can be considered as marginal environments in Western Europe. As breeders don't seem interested in such varieties because of their reproducibility, farmers' selection, together with the inputs of researchers across participatory plant breeding, is a promising way also from an economical point of view for the farmers. Despite these advantages, regulation space is still a question for these OPVs in Europe to allow them to coexist with the commercial hybrids on the market place. If distinctiveness doesn't seem the problem, uniformity and stability required are not possible for diversified varieties but also, for adaptation and some use in organic and low input systems, not suitable. This questions the fact that UPOV registration system is the only way for seed exchanges in Europe and that the current legislation system is not compatible with the valorization of this farmers' work although it was a basis for professional breeders until the beginning of the 20th century. A coexistence of the actual system and a "farmers' varieties" system could however be possible since the needs and wills of both the parts are very different: for example, "guarantee of a product with exact and determined qualities" for the commercial seed sector versus "product that can adapt to specific environments" for the informal farmer seed sector [33]-[37].

\section{Conclusion}

Due to their intrinsic genetic heterogeneity, OPVs are likely to evolve quickly under the combined effect of natural and human mass selection in organic and low input conditions. By combining on station and on farm trials, we showed that several traits of agronomic importance did evolve within only two generations. Farmers' selection is thus a lever for adaptation to marginal environments and doesn't constitute a bottleneck because farmers conserved the diversity of the varieties. These results could be taken into account in order to open a dedicated legislative space for such varieties in Europe.

\section{Acknowledgements}

This publication was financially supported by the European Commission through the STREP project "Farm Seed Opportunities", contract no. 044345, under the 6th Framework Programme, priority 8.1, "Specific Support to Policies".

We would like to thank warmly all the people involved in the experiments: Silvio Pino, from IGSA (Istituto di Genetica e Sperimentzione Agricola) for the management of the Italian trials, Jean-Martial Morel for having taken special care of the on station trial, the INRA team of Le Moulon (Sophie Pin, Nathalie Gallic, Julie Dawson, Pierre Rivière and Isabelle Goldringer) for their help in collecting data on ears and finally and especially all the farmers who have cultivated the OPVs and shared their experience of breeding with us: Jacky Debin, JeanLuc Boisvert, Andde Dubois, Errit Jansingh, Claude Souriau, Bruno Joly and the farmers of the agricultural cooperative "La Fiorita".

\section{References}

[1] Hajjar, R., Jarvis, D.I. and Gemmill-Herren, B. (2008) The Utility of Crop Genetic Diversity in Maintaining Ecosystem Services. A review. Agriculture, Ecosystems and Environment, 123, 261-270. http://dx.doi.org/10.1016/j.agee.2007.08.003

[2] Wolfe, M.S., Baresel, J.P., Desclaux, D., Goldringer, I., Hoad, S., Kovacs, G., Löschenberger, F. Miedaner, T., Østergard, H. and Lammerts van Bueren, E.T. (2008) Developments in Breeding Cereals for Organic Agriculture. Euphytica, 163, 323-346. http://dx.doi.org/10.1007/s10681-008-9690-9

[3] Pixley, K.V. (2006) Hybrid and Open-Pollinated Varieties in Modern Agriculture. Arnel Hallauer International Symposium on Plant Breeding, Mexico, 17-22 August 2003, 234-250.

[4] Kutka, F. (2011) Open-Pollinated vs. Hybrid Maize Cultivars. Sustainability, 3, 1531-1554. http://dx.doi.org/10.3390/su3091531

[5] Gauffaux, R., Goldringer, I., Bonneuil, C., Montalent, P. and Bonnin, I. (2011) Quels indicateurs pour suivre la 
diversité génétique des plantes cultivées ? Le cas du blé tendre cultivé en France depuis un siècle. Fondation pour la Recherche sur la Biodiversité.

[6] Millenium Ecosystem Assessment (2005) Global Assessment Reports. http://www.millenniumassessment.org/en/Global.html

[7] Ceccarelli, S. (1994) Specific Adaptation and Breeding for Marginal Conditions. Euphytica, 77, $205-221$. http://dx.doi.org/10.1007/BF02262633

[8] Tiwari, T.P., Virk, D.S. and Sinclair, F.L. (2009) Rapid Gains in Yield and Adoption of New Maize Varieties for Complex Hillside Environments through Farmer Participation. I. Improving Options through Participatory Varietal Selection (PVS). Field Crops Research, 111, 137-143. http://dx.doi.org/10.1016/j.fcr.2008.11.008

[9] Smith, M.E., Castillo, F.G. and Gomez, F. (2001) Participatory Plant Breeding with Maize in Mexico and Honduras. Euphytica, 122, 551-565.

[10] Mercer, K.L., Perales, H.R. and Wainwright, J.D. (2012) Climate Change and Transgenic Adaptation Strategy: Smaller Livelihoods Climate Justice, and Maize Landraces in Mexico. Global Environmental Change, 22, 495-504. http://dx.doi.org/10.1016/j.gloenvcha.2012.01.003

[11] Li, J., Lammerts van Bueren, E.T., Jiggins, J. and Leeuwis, C. (2012) Farmers’ Adoption of Maize (Zea mays L.) Hybrids and the Persistence of Landraces in Southwest China: Implications for Policy and Breeding. Genetical Resources and Crop Evolution, 59, 1147-1160. http://dx.doi.org/10.1007/s10722-011-9750-1

[12] Mulatu, E. and Zelleke, H. (2001) Farmers’ Highland Maize (Zea mays L.) Selection Criteria: Implication for Maize Breeding for the Hararghe Highlands of Eastern Ethiopia. Euphytica, 127, 11-30. http://dx.doi.org/10.1023/A:1019939721444

[13] Machado, A.T. and Fernandes, M.S. (2001) Participatory Maize Breeding for Low Nitrogen Tolerance. Euphytica, 122, 567-573. http://dx.doi.org/10.1023/A:1017543426136

[14] Vaz Patto, M.C., Moreira, P.M., Almeida, N., Satovic, Z. and Pego, S. (2008) Genetic Diversity Evolution through Participatory Maize Breeding in Portugal. Euphytica, 161, 283-291. http://dx.doi.org/10.1007/s10681-007-9481-8

[15] Farm Seed Opportunities (2010) Conservation, Breeding and Production. FSO European Project, Sixth Framework Programme-Priority 8.1 Special Targeted Research Project.

[16] Desclaux, D., Nolot, J.M., Chiffolleau, Y., Goze, E. and Leclerc, C. (2008) Changes in Concept of Genotype $\times$ Environment Interactions to Fit Agriculture Diversification and Decentralized Participatory Plant Breeding: Pluridisciplinary Point of View. Euphytica, 163, 533-546. http://dx.doi.org/10.1007/s10681-008-9717-2

[17] Serpolay, E., Schermann, N., Dawson, J.C., Lammerts van Bueren, E.T., Goldringer, I. and Chable, V. (2011) Phenotypic Changes in Different Spinach Varieties Grown and Selected under Organic Conditions. Sustainability, 3, 16161636. http://dx.doi.org/10.3390/su3091616

[18] Dawson, J.C., Serpolay, E., Giuliano, S., Schermann, N., Galic, N., Chable, V. and Goldringer, I. (2012) Multi-Trait Evolution of Farmer Varieties of Bread Wheat after Cultivation in Contrasting Organic Farming Systems in Europe. Genetica, 140, 1-17. http://dx.doi.org/10.1007/s10709-012-9646-9

[19] Dawson, J.C., Serpolay, E., Giuliano, S., Schermann, N., Galic, N., Berthellot, J.F., Chesneau, V., Ferte, H., Mercier, F., Osman, A., Pino, S. and Goldringer, I. (2013) Phenotypic Diversity and Evolution of Farmer Varieties of Bread Wheat on Organic Farms in Europe. Genetic Resources and Crop Evolution, 60, 145-163. http://dx.doi.org/10.1007/s10722-012-9822-x

[20] Villain, M. (1999) Méthodes expérimentales en agronomie. Pratique et analyse, Tec \& Doc.

[21] Terzopoulos, P.J. and Bebeli, P.J. (2010) Phenotypic Diversity in Greek Tomato (Solanum lycopersicum L.) Landraces. Scietia Horticulturae, 126, 138-144. http://dx.doi.org/10.1016/j.scienta.2010.06.022

[22] Thomas, M., Dawson, J.C., Goldringer, I. and Bonneuil, C. (2011) Seed Exchanges, a Key to Analyze Crop Diversity Dynamics in Farmer-Led On-Farm Conservation. Genetic Resources and Crop Evolution, 58, 321-338. http://dx.doi.org/10.1007/s10722-011-9662-0

[23] Pimbert, M. (2010) Report on Innovative Approaches in Participatory Research, On-Farm Conservation and the Management of Agricultural Biodiversity in Europe. Farm Seed Opportunities European FP7 Project, Deliverable 2.3. http://pubs.iied.org/pdfs/G02743.pdf

[24] Khan, A. (2013) Short Term Response of European Wheat to Contrasted Agro-Climatic Conditions: A Genetic Analysis and First Step towards Development of Epigenetics Markers in Earliness Genes. Ph.D. Dissertation, Université Paris Sud, Orsay.

[25] Durand, E., Tenaillon, M.I., Ridel, C., Coubriche, D., Jamin, P., Jouanne, S., Ressayre, A., Charcosset, A. and Dillmann, C. (2010) Standing Variation and New Mutations Both Contribute to a Fast Response to Selection for Flowering Time in Maize Inbreds. Evolutionary Biology, 10, 2. http://dx.doi.org/10.1186/1471-2148-10-2 
[26] Moreira, P.M., Pêgo, S.E., Vaz Pato, M.C. and Hallauer, A.R. (2008) Comparison of Selection Methods on "Pigarro", a Portugese Improved Maize Population with Fasciation Expression. Euphytica, 163, 481-499. http://dx.doi.org/10.1007/s10681-008-9683-8

[27] Goldringer, I., Prouin C., Rousset M., Galic N. and Bonnin I. (2006) Rapid Differentiation of Experimental Populations of Wheat for Heading Time in Response to Local Climatic Conditions. Annals of Botany, 98, 805-817. http://dx.doi.org/10.1093/aob/mcl160

[28] Intergovernmental Panel on Climate Change (2013) Climate Change 2013: The Physical Science Basis. http://www.climatechange2013.org/images/report/WG1AR5_ALL_FINAL.pdf

[29] Zhu, Y., Chen H., Fan, J., Wang, Y., Li, Y., Chen, J., Fan, J., Yang, S., Hu, L., Leung, H., Mew, T.W., Teng, P.S., Wang, Z. and Mundt, C.C. (2000) Genetic Diversity and Disease Control in Rice. Nature, 406, 718-722.

[30] Wolfe, M.S. (2000) Crop Strength through Diversity. Nature, 406, 681-682.

[31] Charmantier, A. and Galant, D. (2005) Environmental Quality and Evolutionary Potential: Lessons from Wild Populations. Proceedings of the Royal Society Biological Sciences, 272, 1415-1425. http://dx.doi.org/10.1098/rspb.2005.3117

[32] Louette, D. and Smale, M. (2000) Farmers' Seed Selection Practices and Traditional Maize Varieties in Cuzalapa, Mexico. Euphytica, 113, 25-41. http://dx.doi.org/10.1023/A:1003941615886

[33] Salazar, R., Louwaars, N.P. and Visser, L. (2007) Protecting Farmers New Varieties: New Approaches to Rights on Collective Innovations in Plant Genetic Resources. World Development, 35, 1515-1528. http://dx.doi.org/10.1016/j.worlddev.2006.05.019

[34] Bocci, R., Chable, V., Kastler, G. and Louwaars, N. (2012) Farm Seed Opportunities, Recommendations for on Farm Conservation in Europe. In: Maxted, et al., Eds., Agrobiodiversity Conservation, CABI, Oxfordshire, 137-141.

[35] Andersen, R. and Winde, T. (2013) Forthcoming. Realising Farmers’ Rights to Crop Genetic Resources-Success Stories and Best Practices. Earthscan/Routledge, Oxford.

[36] Baker, B., Bocci, R., Chable, V., Louwaars, N. and Hubbard, R. (2012) Plant Breeding, Varieties Release, and Seed Commercialization: Laws and Policies Applied to the Organic Sector. In: Lammerts van Bueren, E. and Myers, R., Eds., Organic Plant Breeding, Wiley-Blackwell, Hoboken.

[37] Bocci, R. (2009) Seed Legislation and Agricultural Biodiversity-Conservation Varieties. Journal of Agriculture and Environment for International Development, 103, 1-2. 